\title{
Understanding cashless payments in India
}

\author{
Bappaditya Mukhopadhyay
}

\author{
Correspondence: \\ bappa.mukh@gmail.com \\ Great Lakes Institute of \\ Management, Bilaspur Tauru road, \\ Gurgaon, Haryana 122413, India
}

\begin{abstract}
Background: This paper analyzes India's gradual transition towards a cashless economy.

Methods: We present a theoretical model that evaluates decisions by consumers and sellers to adopt cashless payments. We then use data from surveys conducted in 2011 and 2014 (from World Bank's Global Findex), as well as household and enterprise surveys conducted in 2009-2010 to estimate the amount of cashless transactions prevalent in India and identify the avenues that are successful and those that are not. We analyze instruments (cards versus point-of-sale versus mobile), micro units (individuals versus households versus retailers), and sectors to identify and estimate the enablers and bottlenecks.

Results: We find that the most crucial enabler of cashless payments are inflows of funds into the accounts.

Conclusion: Based on our findings, we suggest possible policy interventions.

Keywords: Cashless transactions, Survey, Network effect

JEL classification: G18, G29, O53
\end{abstract}

\section{Background}

Globally, there is a tremendous interest among policy makers, academicians, and commercial enterprises to explore the possibilities of moving towards a cashless economy. It is widely believed that the movement from cash to cashless economy has significant benefits. Moody's Analytics (2013), studying the impact of card usage on gross domestic product (GDP) of 51 countries, found that electronic card usage added USD 1.1 trillion in real dollars to private consumption and GDP from 2003 to 2008. The study found that a $1 \%$ increase in card transaction volume would increase consumption each year by $0.039 \%$ and GDP growth by $0.024 \%$. Similar benefits are expected for India as well. In this paper, apart from identifying some of these benefits for India, there are two major issues we address: the share of cashless -both in terms of transactions as well as value and the factors that affect them most. This provides a roadmap to increasing the share of cashless transactions in the economy.

As Per the World Payments Report (2015), global non-cash transactions reached 358 illion in 2013, an increase of 7.6\% over 2012. Further, European Central Bank (ECB) data on access and use of payment instruments and terminals, show a steady graduation towards cashless payments (Table 1).

The total number of non-cash payments in the EU increased by $2.8 \%$ in 2014 over 2013 and by $6.0 \%$ in 2013 over 2012. During the period 2000-2014, while credit

(c) The Author(s). 2016 Open Access This article is distributed under the terms of the Creative Commons Attribution 4.0 International License (http://creativecommons.org/licenses/by/4.0/), which permits unrestricted use, distribution, and reproduction in any medium, provided you give appropriate credit to the original author(s) and the source, provide a link to the Creative Commons license, and indicate if changes were made. 
Table 1 Cashless payments in EU

\begin{tabular}{llll}
\hline Payment Instruments & Unit & 2013 & 2014 \\
\hline Non Cash transactions & billions & 100 & 103.2 \\
Card payments & billions & 44 & 47.5 \\
Value of card payments & trillion Euros & 2.2 & 2.4 \\
Credit transfer & billions & 27 & 27 \\
Direct debit & billions & 24 & 21.9 \\
Payment cards per inhabitant & times & 1.5 & 1.5 \\
ATMs & millions & 0.43 & 0.49 \\
POS & millions & 9.1 & 10.1 \\
\hline
\end{tabular}

Data source: https://www.worldpaymentsreport.com/

transfers and direct debits increased linearly, card payments increased exponentially. Furthermore, automated teller machine (ATM) withdrawals decreased as well, implying an increasing substitution of cash by cashless payment instruments, similar to the USA. Galbraith and Tkacz (2015) estimate that, for the USA, the number of debit card transactions grew by about $13.0 \%$, compounded annually over the period 2003-2012, and $5.1 \%$ compounded annually for credit cards over the same period. However, ATM withdrawals fell slightly, as did the number of checks written by approximately $6.2 \%$, establishing a likely substitution of cash by cashless payments.

Recent studies highlight the multiplier effect of cashless payments on GDP growth. Zandi et al. (2013), studying 56 countries over 2008-2012, calculate that USD 983 billion were added to their cumulative real GDP because of increased card usage. This amounts to $0.3 \%$ of their GDP per year. They estimate that a future $1 \%$ increase in card usage across these countries would produce an annual consumption increase of $0.056 \%$ and a GDP increase of $0.032 \%$. Among the major emerging economies, a $1 \%$ increase in card usage will increase consumption by $4.89 \%$ in China, $1.070 \%$ in Russia, $1.147 \%$ in Brazil, with India at a lower level of $0.047 \%$. In another related study, Hasan et al. (2013) analyze retail payments data from all 27 European Union member states over the period 1995-2009. This study also demonstrates the positive relation between migration from paper to electronic retail payments to the real economy. They estimate that if the card penetration ratio increases by $1.2 \%$ in the EU, then GDP would increase by $0.07 \%$ or about 6 million Euro. ${ }^{1}$

The question is how does the growth in cashless payments fuel the economy. The literature suggests two prominent direct benefits of cashless payments on GDP growth: lower costs of storing and processing physical currency and increased tax collection. Bolt et al. (2008), using payment and banking data between Netherlands and Norway (1990-2004), estimate that using cashless payment instruments may save 0.7 billion Euro in bank costs for Norway (0.35\% of GDP in 2004) and 2.9 billion Euro for the Netherlands ( $0.61 \%$ of GDP). This means that, on a discounted basis over time, shifting from 90\% paper-based instruments and cash to 90\% electronic and card instruments could save about 2300 Euro per person in each country. Kruger and Seitz (2014) estimate the cost by simply multiplying a representative hourly wage rate and the total number of ATM withdrawals per year. They indicate a significant saving if an economy graduates to cashless payments. 
Going cashless may lead to higher tax collection as well. Kearney and Schneider (2011, 2013) estimate the shadow economy in Europe and establish a strong negative correlation between the size of cashless transactions and the size of the shadow economy. Madzharova (2014) looks at the possible linkages of tax compliance with types of payments and investigates if there is any association between the method of payment and VAT revenue outcomes. Using country-level panel data for $26 \mathrm{EU}$ countries in the period 2000-2010, the paper shows a consistently negative impact of cash payments on VAT collection.

In this paper, we only focus on some of the benefits of going cashless in India. To the existing body of the literature, our contribution is developing an insight both at a micro level (households and retailers), as well as to what sectors are likely to implement more cashless payments than others. Insights from our findings will be invaluable towards developing a roadmap for promoting cashless payments. To the best of our knowledge, such analysis at a disaggregated level has not been done at country level, as the focus of literature has been on estimating cashless payments, its macro-economic effects, instruments, and regulations that can promote cashless payments.

There are both direct as well as indirect benefits of going cashless for India. We list them below.

\section{Direct Benefits:}

(a) High maintenance costs

According to the Reserve Bank of India (RBI), the provisional estimates of the amount of currency in circulation (as of June 2016) stand at INR 16.61trillions, out of which only 5\% of the currency is with the bank. From April 1994 to June 2016, currency has shown a yearly growth rate of $17 \%$, while the share of bank currency has remained around 5\%. ${ }^{2}$ It was estimated that, for 2009-2010, RBI incurred an annual cost of INR 2800 Crores for printing currency notes (Das and Agarwal 2010). This is $0.4 \%$ of the total currency in circulation. ${ }^{3}$ This cost does not include the cost of storage, transportation, security, detection of counterfeits, etc. In addition to the printing cost, if we were to add the cost of storage and maintaining these currencies through ATMs alone, the cost of printing and distributing cash constitutes about $0.2 \%$ of India's GDP. Given these costs, moderate growth of cashless transactions by $5 \%$ a year will save more than INR 500 Crores annually.

(b) Financial records and tax collections

Although it is difficult to obtain accurate estimates of the amount of "black money" in the country, it is certainly significant, both in terms of value and as a percentage of GDP. ${ }^{5}$ As a prevention strategy, the Government has recently announced an immediate demonetization of all high-value currencies. Schneider (2006) estimates the size of India's black money economy between $23 \%$ and $26 \%$ of the GDP. Some recent estimates consider it between $40 \%$ and $75 \%$ of the GDP. ${ }^{6}$ In addition, India is among the low tax collection countries. Economic Index of Freedom data estimates the tax burden in India (tax revenue as a percentage of GDP) at only at $17.6 \%$, which is lower than the global average of above $25 \%{ }^{7}$ The lower tax burden is mostly due to low tax compliance, as well as a complicated tax structure. While the 
direct tax rate is $30.9 \%$ in India, as opposed to a global average of $35.6 \%$, only $1 \%$ of the total population in India pays income tax. ${ }^{8}$ The effort is therefore to increase indirect tax collection. With cashless transactions, all transactions would leave digital footprints. A system that encourages and incentivizes the "buyer" to pay through cashless instruments (increasing use of bank-to-bank transactions without involving physical currency) will have higher financial transparency. This is perhaps the most direct way of battling issues of corruption and black money in India. Recently, Bhattacharya and Singh (2015) use a panel of 54 countries over 2005-2013 and find a strong causality between high currency notes and corruption.

For India, perhaps, the indirect benefits of going cashless are stronger. We highlight two benefits, which are particularly important in the Indian context. The first one is promoting financial inclusion and the second is a better targeting of benefits.

Indirect benefits:

\section{(a) Financial inclusion}

The percentage of population covered by the banking system is still low in India (slightly above 60\%), despite recent improvements. The push towards financial inclusion in India has emanated from the Pradhan Mantri JanDhan Yojana in August 2014, the Jan Dhan Aadhaar Mobile trinity articulated in the Government's Economic Survey 2014-2015, as well as the special thrust on financial inclusion by the Financial Stability and Development Council. As of July 2016, approximately 228 million accounts have been opened under the PMJDY scheme. However, a quarter of them are zero-balance accounts. ${ }^{9}$ The biggest challenge to financial inclusion is that the accounts opened under such schemes mostly lie dormant (Gangopadhyay 2009). Various models have tried to activate the accounts with mixed results. India has tried the banking correspondence model, drawing upon the experiences of Latin American countries such as Brazil and Mexico with this model (Birochi and Pozzebon, 2012), the Bolsa Familia, a conditional cash transfer program in Brazil, and mobile banking technology in Kenya, Uganda, Tanzania, and other African nations (Demirguc-Kunt and Klapper 2012). However, mobile banking is perhaps best suited to solve the problem of connecting to users to the banks. Most previous models in India have focused on how to make it easier for the individuals to access cash. The focus should be on how efficiently can they carry forth their financial transactions.

(b) Stopping leakages

A cashless economy could stop leakages. In 2009, the Planning commission estimated that only 27\% of Public Distribution System expenditure reached the targeted lowincome groups. ${ }^{10}$ The use of computerized platforms to keep record of all transactions pertaining to government-to-person (G2P) payments can have a significant impact on the economy as a whole in terms of efficiency, safety, and transparency. It also brings previously unbanked beneficiaries into the fold of formal financial services by channeling a regular flow of money into their accounts. Evidence from other countries shows this to be already in operation. In South Africa, over $80 \%$ of beneficiaries receive government transfers into an account and the percentage is as high as $88 \%$ in Brazil. Mexico's shift to digital G2P payments led to a cut in spending 
on wages, pensions, and social benefits by $3 \%$ annually. Compared to this, G2P payments comprised less than $10 \%$ of total transfers for India. We now present a theoretical model that addresses the direct benefits of going cashless.

\section{Methods}

The theoretical literature on payment system models such as a two-sided market, emphasize the role of interchange fees in balancing demand by cardholders and merchants to maximize network benefits (Baxter 1983; Rochet and Tirole 2003, 2004). One of the earliest studies on two-sided markets is Baxter (1983). He uses a four-party model involving financial transactions using checks, debit cards, and credit cards. The paper analyzed interbank pricing, as well as the regulatory framework that supports it. Rochet and Tirole (2004) establish that, because pricing to one side is designed with an eye on externalities on the other side, standard pricing principles often do not apply. Platforms must perform the balancing act between both the sides and not only with respect to the price structure. These platforms, therefore, often regulate the terms of the transactions between end-users, screen members in non-price related ways, and monitor intra-side competition. Wright (2003) determines the limits on the extent to which interchange fees can matter. When merchants earn negligible surplus (due to intense retail competition), interchange fees cannot play their normal reallocative role. Instead, facing the no-surcharge rule, merchants will specialize in catering either to cash- or card- paying customers. With merchant surcharges allowed, merchants surcharge excessively, resulting in too little holding and usage of cards. In the case consumers first face a membership cost of joining the card network, the undersubscription can be extreme.

Switching from a cash based economy to a cashless economy would require a concerted effort to develop a network of critical mass that deals with cashless transactions. Network effects are in place when an addition of one more individual to an existing network of individuals increases the value of all the members in the current network. This makes it costlier for the existing members to switch from the current network. With each additional cashless transaction, the value to all the members currently using cash increases. In simple words, users find it more attractive to switch to cashless transactions if more users are using them (Shy and Tarakka 2002). Therefore, it is important that policy initiatives are in place to develop a critical mass of this network of non-cash users.

Based on the evolution of card payments in India, an appropriate framework must address the following issues. It must model:

- cashless payments as a two-sided matching market;

- explicitly state the costs of joining the network as well as the cost per transaction; and

- the possibility of paying higher taxes if one uses cashless payments.

We subsequently present a simple model that takes these points into consideration.

\section{Basic model}

We set up the basic model of consumers' and sellers' payment decisions. 
Consumers: Consumers are not identical. First, they differ with respect to disposable income and, second, they differ across their investments in the cashless infrastructure. The income, $M$, is private knowledge of the consumer. All others know that it is distributed over the range, $0, \bar{M}$ with the associated probability distribution $F(M)$ and the probability density function $f(M)$, such that $F(0)=0, F(\bar{M})=1$. For the consumers the investment in a cashless infrastructure comes at a fixed cost of $E_{C}$. One can envisage such fixed costs as opening a bank account, paying joining fees to a credit card company or fees charged to obtain a debit card, buying a smartphone, etc. In other words, this cost is independent of the volume of cashless transactions made. We assume that the proportion of consumers who have already incurred $E_{C}$ in the population is $\theta_{C}$. The other group, who have not invested in the cashless platform, can only transact using cash. Assumption A.1 states the acceptability of cashless payments.

A.1: If a consumer wants to pay by card and if the seller has a point-of-sale (POS) installed, the seller must accept card payment.

A.1 ensures that no seller can refuse card payments if a POS is installed. We only need to impose this assumption on the seller and not the buyer, as the buyer initiates the payment. We assume that, while the buyer can insist on card payments, the sellers cannot. This is further strengthened by the fact that the seller cannot observe the buyer, while the buyer can observe whether the seller has a POS or not. Note that we do not need to assume the same about cash, as cash is a legal tender and no seller can refuse cash unless it is prohibited by law. Let the representative vector of goods that a consumer purchases be denoted as $X$.

If the individuals want to buy $x$ units of good $X$, the utility function for individuals from consuming an amount $x$ at price $p_{x}$ is given by $(x) ; U_{x}>0$. Further, there is an indirect tax (sales and/or service tax, etc.) of $t_{x}$. If cashless payments are made to buy the good this indirect tax cannot be avoided. However, if one makes cash payments, then it is entirely possible to avoid paying this tax.

Sellers: Similar to the consumers, there are two types of sellers. The first group consists of all sellers who have invested in cashless platforms (say POS devices or mobile payment accounts) incurring a fixed cost of $E_{F}$ while the second group has not. The proportion of the first group of sellers is $\theta_{F}$. The sellers who have installed a POS can serve both types of consumers, while those who have not can only serve consumers without cards. However, if the transaction is done using a card, the indirect tax record is traceable and, hence, the seller must pay a direct tax, $\tau$ on the sales. For any transaction that does not leave a digital footprint, the direct tax is avoided by the seller.

Equilibrium: If the consumer has incurred $E_{C}$, his disposable income is now lowered by that amount. Thus he/she solves,

$$
\operatorname{Max}_{x} \quad U(x) \quad \text { s.t } \quad p_{x} \cdot x\left(1+t_{x}\right) \leq M-E_{C}
$$

which yields,

$$
x_{E}=\frac{M-E_{C}}{p_{x}\left(1+t_{x}\right)}
$$

If the consumer pays cash, then he/she must incur a cost of $\phi_{c}$ per transaction (e.g., the cost of physically being present for the transaction etc.) Thus he/she solves, 


$$
\operatorname{Max}_{x} U(x) \quad \text { s.t } \quad p_{x} \cdot x\left(1+\phi_{C}\right) \leq M
$$

which yields,

$$
x_{0}=\left\{\begin{array}{cc}
x_{0}^{1} \equiv \frac{M}{p_{x}+\phi_{C}} & \text { if } E_{C} \text { is not incurred } \\
x_{0}^{2} \equiv \frac{M-E_{C}}{p_{x}+\phi_{C}} & \text { if } E_{C} \text { is incurred }
\end{array}\right.
$$

A.2: $p_{x} t_{x}<\phi_{C}$

A.2 implies that the amount of indirect tax paid by the consumer for a transaction is below the costs associated with withdrawing and processing cash. A.2 is a necessary condition for a consumer to make a card payment. A.2 implies that the amount of indirect tax paid by the consumer for a transaction is less than the costs associated with withdrawing and processing cash for the same. A.2 is a necessary condition for a consumer to make a card payment. Note that, if A.2 is violated, then $x_{E}<x_{2}^{0}<x_{1}^{0} \Rightarrow x_{E}<x_{0}$ implying that no consumer will ever make card payments even if they have cards. A.2 is not a sufficient but necessary condition for card. Whether he/she is able to make card payments depend upon the probability with which he encounters a seller who is willing to accept card payments. This probability in our model is given by the proportion of sellers, $\theta_{F}$, who have installed POS. The individual incurs $E_{C}$ if

$$
\theta_{F} U\left(x_{E}\right)+\left(1-\theta_{F}\right) U\left(x_{0}^{\prime}\right)-E_{C} \geq U\left(x_{0}\right)
$$

The left-hand side is the expected utility if cost is incurred. This has two parts. With probability $\theta_{F}$ he/she encounters a seller who accepts card. In this case, he/she buys $x_{E}$. With a probability of $1-\theta_{F}$, he/she encounters a seller who does not accept cards, in which case he/she buys $x_{0}^{\prime}$.

Note, $x_{0}^{\prime}=\frac{M-E_{C}}{p_{x}+\phi_{C}}$. The right hand side depicts the case when he has not incurred the cost and therefore can only make cash payments and hence, can only buy $x_{0}$.

Assuming linear utility function, we get,

$$
\theta_{F} \frac{M-E_{C}}{p_{x}\left(1+t_{x}\right)}+\left(1-\theta_{F}\right) \frac{M-E_{C}}{p_{x}+\phi_{C}} \geq \frac{M}{p_{x}+\phi_{C}} .
$$

Note that the second term on the left hand-side corresponds to the case where $E_{C}$ is already incurred and hence the disposable income is now $M-E_{C}$. This can be rewritten as,

$$
M \geq \widetilde{M} \equiv \operatorname{Max}\left\{\bar{M}, E_{C} \frac{p_{x}+\phi_{C}+\left[1-\theta_{F}\right] p_{x}\left(1+t_{x}\right)}{\theta_{F}\left[\phi_{C}-p_{x} t_{x}\right]}\right\}
$$

Where $\widetilde{M}$ is the critical level of income. This means all consumers whose income exceeds $\widetilde{M}$ will invest in the cashless platform while all those below $\widetilde{M}$ will not.

Proposition 1 The probability of finding individuals who will join the cashless payment system increases as

\footnotetext{
- cost of withdrawal and opportunity time cost of being physically present for the transaction increases,

- more and more sellers join the cashless network
} 
- joining fee decreases

- price of the commodity decrease; and

- indirect tax decrease.

Proof The probability of finding a individual who is willing to join the cashless system is simply, $1-F(\widetilde{M})$. It is straightforward to see that $\widetilde{M}$ is increasing in $E_{C}, p_{x}, t_{x}$ and decreasing in $\phi_{\mathrm{C}}$ and $\theta_{F}$.

Note that a higher $\widetilde{M}$ is the minimum income a consumer must have in order to join the cashless network. Therefore, a higher $\widetilde{M}$ is equivalent to fewer consumers adopting cashless payment systems. Unsurprisingly, if the joining fee increases, fewer consumers will want to incur it. The reason why $\widetilde{M}$ increases with the price of the good as well as the indirect tax is the same. A higher unit price or tax rate means the consumer must pay more for cashless payments, thus making them less attractive. On the other hand, if individuals have a high opportunity cost, mainly in terms of time spent to be physically present for a transaction, investment in cashless becomes more attractive thereby lowering $\widetilde{M}$. Finally, as more and more sellers start accepting cards, more and more consumers invest in cashless payments as the probability of the consumers being able to use the cards increase.

For the sellers, whether or not he incurs the cost depends upon, whether,

$$
\int_{\widetilde{M}}^{\bar{M}} p_{x} x_{E}(1-\tau) d F(M)+\int_{0}^{\widetilde{M}}\left(p_{x}-\phi_{F}\right) x_{0}^{1} d F(M)-E_{F} \geq \int_{\widetilde{M}}^{\bar{M}}\left(p_{x}-\phi_{F}\right) x_{0}^{2} d F(M)+\int_{0}^{\widetilde{M}}\left(p_{x}-\phi_{F}\right) x_{0}^{1} d F(M)
$$

The left-hand-side is the expected payoff to a seller if he/she has invested in POS at a cost $E_{F}$. The probability that the seller meets a consumer who has invested in cashless is $1-F(\widetilde{M})$ and the probability that he comes across a consumer who has not is $F(\widetilde{M})$. If the seller encounters a consumer who has invested in cards, then if the consumer offers to pay by card (A.2) the seller cannot refuse (A.1). All these consumers $(M \geq \widetilde{M})$ buy $x_{E}$ units using cards. Given that this leaves digital footprints, the seller has to pay direct tax equal to the amount $p_{x} x_{E} \tau$. This is the first term on the left hand-side of Eq (6). The seller can also encounter a consumer who has not invested in cards. These are consumers with $M<\widetilde{M}$ who pay by cash to buy $x_{0}^{1}$. We assume that the seller can easily remove any record for this transaction and hence will not pay direct tax on it. This is the second term of the left hand-side of Eq. (6). The final term in the left hand-side of this equation is the joining fee for the seller, $E_{F}$. The right hand-side of Eq. (6) is the expected payoff to the seller when he/she has not installed POS. If he/she encounters a consumer who has cards, the consumer will buy $x_{0}^{2}$ units while if the consumer does not have cards, the consumer will buy $x_{0}^{1}$. Note that neither of the two transactions will have any records and hence the seller need not pay direct tax on them.

Using the expressions for $x_{0}^{2}$ and $x_{E}$, one can rewrite the above as,

$$
\left[\frac{1-\tau}{1+t_{x}}-\frac{p_{x}-\phi_{F}}{p_{x}+\phi_{C}}\right] \int_{\widetilde{M}}^{\bar{M}}\left(M-E_{C}\right) d F(M) \geq E_{F}
$$


A.3: $\left[\frac{1-\tau}{1+t_{x}}-\frac{p_{x}-\phi_{F}}{p_{x}+\phi_{C}}\right]>0$

Note that A.3 is necessary for the seller to invest in POS. A.3 implies, for low tax levels, i.e., $\tau, t_{x} \rightarrow 0$, the condition is automatically satisfied.

Note Eqs. (5) and (7) gives us the upper bound of the joining fee for both the consumer and the seller.

Proposition 2 If no seller (consumer) invests in POS (cards), no consumer (seller) will invest in cards (POS).

Proof From Eq. (5) it is evident that if $\theta_{F} \rightarrow 0, \widetilde{M} \rightarrow \bar{M}$, implying as no seller invests in POS, there are no consumers who invest in cards. Considering Eq. (7), if no consumer invests in cards, that is if $\widetilde{M}=\bar{M}$, then with $E_{F}>0$, Eq. (7) is not satisfied. Thus, no seller wants to invest in POS.

Proposition 2 strongly displays the network effect. One can argue that unless a minimum critical proportion of consumers (sellers) invest in cashless instruments, sellers (consumers) will not invest as well. To calculate these critical levels, one needs to look at the steady state equilibrium.

Proposition 3 There are two steady state equilibria. In the first one, if

(i) $E_{C} \frac{\phi_{C}+p_{x}}{\phi_{C}-p_{x}}<\bar{M}$ and

(ii) $\left[\frac{1-\tau}{1+t_{x}}-\frac{p_{x}-\phi_{F}}{p_{x}+\phi_{C}}\right]^{\bar{M}}\left(M-E_{C}\right) d F(M) \geq E_{F}$

$$
E_{C} \frac{\phi_{C}+p_{x}}{\phi_{C}-p_{x}}
$$

then all firms invest in POS while some consumers invest in cards.

If either of the two conditions are not met, neither of them invest in cashless payments.

Proof From Proposition 2 it is evident that either both parties invest in cashless or none do. The condition for both parties investing in cashless is given by (i) and (ii).

Proposition 4 The probability of investing in cashless instruments for the consumer as well as the seller increases as $E_{C}, E_{F}$ and $t_{x}$, $\tau$ decreases.

Proof The proof follows from Eqs. (5) and (7).

The above results suggest the decision to invest in cashless instruments by either party depends upon (a) the network size and (b) the advantages of going cashless (lower transaction costs) vis a vis its disadvantages (indirect taxes and joining fees). We subsequently explore the role of the government in promoting cashless payments.

\section{Role of government}

The Government in our model has two important roles. First, it collects taxes and, second, it promotes cashless transactions. There is a trade-off between these two actions. High tax levels may mean higher tax revenues, but also discourage consumers and sellers from investing in cashless instruments. This, in turn, means fewer individuals paying taxes. Therefore, there is the possibility that announcing higher taxes may actually lower expected tax collections. Indeed, this is often cited as a reason for tax evasion in India.

Denote, $W\left(\tau, t_{x}, E_{C}, E_{F}\right)$ as the aggregate welfare in the system. The aggregate welfare in the economy is the aggregate of three payoffs- the total tax and fee collections by 
the government, $T$, the aggregate welfare of the consumers, $W_{C}$ and the sellers' net surplus, $W_{F}$. Thus,

$$
\begin{aligned}
W_{C} & =\int_{\widetilde{M}}^{\bar{M}}\left[U\left(x_{E}\right)-p_{x}\left(1+t_{x}\right) x_{E}-E_{C}\right] d F(M)+\int_{0}^{\widetilde{M}}\left[U\left(x_{0}^{1}\right)-\left(p_{x}+\phi_{C}\right) x_{0}^{1}\right] d F(M) \\
W_{F} & =\int_{\widetilde{M}}^{\bar{M}}\left[p_{x}(1-\tau) x_{E}\right] d F(M)+\int_{0}^{\widetilde{M}}\left(p_{x}-\phi_{F}\right) x_{0}^{1} d F(M)-E_{F} \\
T & =\int_{\widetilde{M}}^{\bar{M}} p_{x} t_{x} x_{E} d F(M)+\int_{\widetilde{M}}^{\bar{M}} p_{x} \tau x_{E} d F(M)+E_{C}[1-F(\widetilde{M})]+E_{F}
\end{aligned}
$$

Therefore, using Eq. (8) in $W=W_{C}+W_{F}+T$ we obtain,

$$
W=\frac{1}{p_{x}\left(1+t_{x}\right)} \int_{\widetilde{M}}^{\bar{M}} M d F(M)+\frac{1-\left(\phi_{C}+\phi_{F}\right)}{p_{x}+\phi_{C}} \int_{0}^{\widetilde{M}} M d F(M)
$$

Note that as the tax collection and the fees are a mere transfer between the consumers and the sellers to the government. Therefore, it does not appear in the expression of the aggregate welfare. However, they still affect the overall welfare as the proportion of consumers and sellers who will invest in cashless payment systems depends upon these.

We assume that the government only sets $E_{C}, E_{F}$ in our model. In other words, the tax rates are exogenous to the model. We are interested in an economy where the government is evaluating the impact of cashless transactions and only sets the joining fees of the two parties. In other words, in our model, the tax rates have already been decided by the Fiscal committee and we are interested in how the Government promotes cashless payments given the existing tax rates. ${ }^{11}$

Note that from Proposition 2, there are two steady-state equilibria: one where all sellers invest in POS and the other where none do.

Lemma $1 W\left(E_{C}\right)$ is decreasing in $E_{C}$.

$$
\text { Proof } \begin{aligned}
W & =\frac{1}{p_{x}\left(1+t_{x}\right)} \int_{\widetilde{M}}^{\bar{M}} M d F(M)+\frac{1-\left(\phi_{C}+\phi_{F}\right)}{p_{x}+\phi_{C}} \int_{0}^{\widetilde{M}} M d F(M) \\
\frac{d W}{d E_{C}} & =\left[\frac{-\widetilde{M}}{p_{x}\left(1+t_{x}\right)}+\frac{1-\left(\phi_{C}+\phi_{F}\right)}{p_{x}+\phi_{C}} \widetilde{M}\right] \widetilde{M} f(\widetilde{M}) \frac{\partial \widetilde{M}}{\partial E_{C}} \\
& =\left[\frac{1-\left(\phi_{C}+\phi_{F}\right)}{p_{x}+\phi_{C}}-\frac{1}{p_{x}\left(1+t_{x}\right)}\right] \widetilde{M} f(\widetilde{M}) \frac{\partial \widetilde{M}}{\partial E_{C}}
\end{aligned}
$$

Given A.2, and $\frac{\partial \widetilde{M}}{\partial E_{C}}>0$, it is obvious that $\frac{d W}{d E_{C}}<0$.

Lemma 1 states that aggregate welfare decreases as the joining fee for the consumers increases. The reason is simple: a higher joining fee means fewer consumers who join 
cashless networks, implying fewer cashless transactions. Given that an advantage of cashless payments is that it saves on transaction costs, the aggregate welfare reduces.

Proposition 5 The Government should set the joining fee for the consumers as low as possible, so that the steady-state equilibria involving cashless payments are enabled.

Proof Consider the steady state where no cashless payments are made. In this case, $\widetilde{M}=\bar{M}$. The aggregate welfare in this case is, $W\left(. \mid \theta_{F}=0\right)=E(M) \frac{1-\phi_{C}-\phi_{F}}{p_{x}+\phi_{C}}$.

The other steady state equilibrium has, $\theta_{F}=1$. In this case, if the government sets $E_{C}=0$, then $\widetilde{M}=0$ and the aggregate welfare is $W\left(. \mid \theta_{F}=1\right)=\frac{E(M)}{p_{x}\left(1+t_{x}\right)}$. Given A.2,

$$
W\left(. \mid \theta_{F}=1\right)=\frac{E(M)}{p_{x}\left(1+t_{x}\right)}>W\left(. \mid \theta_{F}=0\right)=E(M) \frac{1-\phi_{C}-\phi_{F}}{p_{x}+\phi_{C}}
$$

This implies the aggregate welfare is higher when cashless transactions take place. Further, note that as $W()$ is decreasing in $E_{C}$, the Government must set the minimum $E_{C}$.

The key recommendation that follows from proposition 5 is that the government must ensure that the joining fee for the consumers are kept at a minimum. It also establishes that the aggregate welfare is higher if the government promotes cashless transactions as opposed to preventing them.

We subsequently evaluate the status of cashless economy in India.

\section{Results and Discussions}

In this section, we present a micro unit-level analysis. We use data from the World Bank's Global Findex surveys conducted in 2011 and $2014 .{ }^{12}$ A report based on the database shows how financial inclusion is increasing over the years (Demirguc-Kunt et al 2014). The Global Findex survey had 149,761 respondents from 143 countries in 2011 and 146,688 from 142 countries in 2014. The database provides in-depth information on how individuals save, borrow, make payments, and manage risks. The database also has 3518 and 3000 respondents from India in 2011 and 2014, respectively. In Table 2, we describe the key sample characteristics of the Findex data.

Table 2 Sample Characteristics Global Findex Surveys

\begin{tabular}{llll}
\hline Items & Units & Microdata 2011 & Microdata 2014 \\
\hline Variables & Numeric & 53 & 86 \\
Observations & Numeric & 149,761 & 146,688 \\
Countries & Numeric & 143 & 142 \\
Male & Numeric & 68,740 & 68,866 \\
Median Age & Numeric & 40 & 42 \\
Income Poorest 20\% & Percentage & 16.55 & 16.67 \\
Income Richest 20\% & Percentage & 25.65 & 24.80 \\
Education: Completed Primary & Percentage & 33.53 & 33.38 \\
Education: Completed Secondary & Percentage & 51.36 & 50.03 \\
Education: Completed Tertiary & Percentage & 14.58 & 16.14 \\
Bank Accounts & Percentage & 46.39 & NA \\
Accounts in Formal Fls & Percentage & 49.50 & 56.18 \\
\hline
\end{tabular}

Data source: http://www.worldbank.org/en/programs/globalfindex NA denotes missing fields in the survey 
Note that, in 2011, $49.50 \%$ of the sample respondents had an account with a financial institution, whereas the percentage increased to $56.18 \%$ in 2014 . During the same time frame, global estimates rose from $51 \%$ to $62 \%$.

\section{Cashless: global trend}

In Table 3, we provide key financial transaction indicators across countries. The percentages calculated are based on the banked population only. This is because, the extent of cashless payments made by unbanked individuals is usually negligible. Given that the variables are not uniform across the two surveys, some comparisons are not possible across the two time periods. For example, while in 2014 the respondents are explicitly asked whether they have used credit or debit cards to make any retail payments in the last one year, this was not asked in previous surveys. Therefore, to compare across the two time periods, we restrict cashless transactions to only those payments not made either by cash or checks. The key observations are that: (a) the percentage of households who make such cashless transactions almost doubled from $22.77 \%$ to $44.33 \%$; (b) mobile payments have increased four-fold, from $3.06 \%$ to $12.61 \%$; while (c) the percentage of dormant accounts have increased from 7.715 to $15.01 \%$. These three observations suggest a pattern. First, more individuals are globally making cashless payments; second, mobile payments are on the rise; and, third, there is a drive among most governments to expand the banked population.

We now explore the possible reasons as to why some countries have higher proportions of individuals making cashless payments. For 2011, in Fig. 1, we present the scatter plots across key variables for all countries, while, in Fig. 2, we plot the scatter for cashless payments versus payments received in accounts for G20 countries.

The variables cashless indicates cashless payments including check payments, and cashless indicates cashless payments without check payments. The positive correlations

Table 3 Global Financial Transactions

\begin{tabular}{llll}
\hline Items & Units & Microdata 2011 & Microdata 2014 \\
\hline Dormant Accounts & Percentages & 7.71 & 15.01 \\
Receives Payments in Accounts & Percentages & 38.63 & 40.02 \\
Receives Wage in Accounts & Percentages & NA & 25.39 \\
Receives Government Transfers in Accounts & Percentages & 21.41 & 11.73 \\
Receives Mobile payments & Percentages & NA & 4.28 \\
Receives Remittances in Accounts & Percentages & 14.84 & 27.46 \\
Receives Remittances in Mobile & Percentages & NA & 2.88 \\
Makes Mobile Payments & Percentages & 3.06 & 12.61 \\
Makes e payments & Percentages & 20.79 & NA \\
Makes Check Payments & Percentages & 16.98 & NA \\
Makes Online Payments & Percentages & NA & 19.71 \\
Makes MTO & Percentages & NA & 4.11 \\
Makes remittances in mobile & Percentages & 4.7 & 3.08 \\
Makes Cashless payments & Percentages & 31.77 & NA \\
Makes Cashless payments (no checks) & Percentages & 22.77 & 44.33 \\
\hline
\end{tabular}

Data source: http://www.worldbank.org/en/programs/globalfindex 


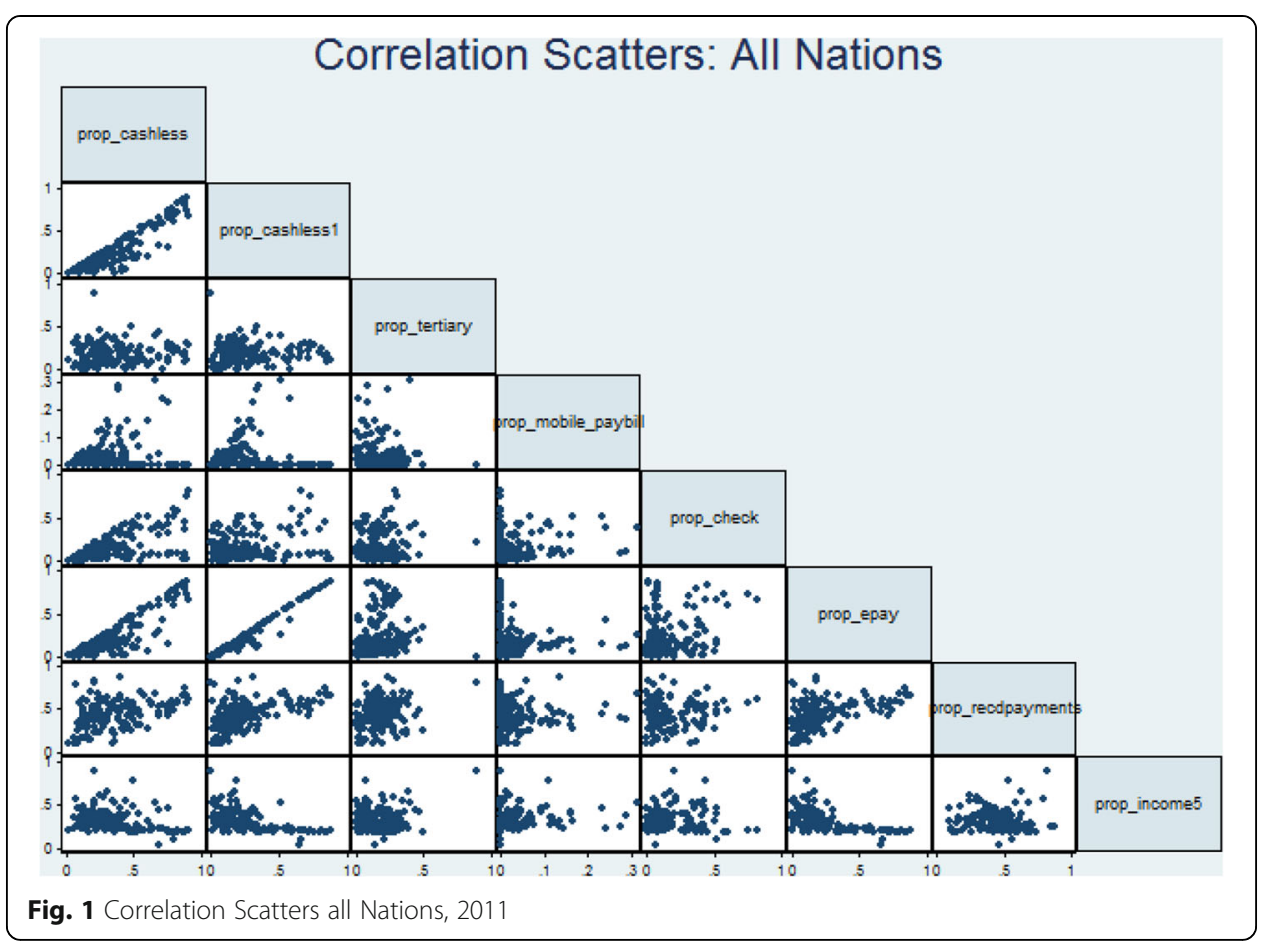

between cashless payments and e-payments/check payments/mobile payments are not surprising, as cashless payments are defined with respect to such payments. However, what is of interest are the remaining three items: proportion of individuals who have completed tertiary level of education (prop_tertiary), individuals who are in the top $20 \%$ of the income bracket (prop_income5), and proportion of individuals who received payments in their accounts (prop_recdpayment). While there is very little correlation between cashless payments and either education level attained or income earned, there is a strong positive correlation between the proportion of individuals who receive

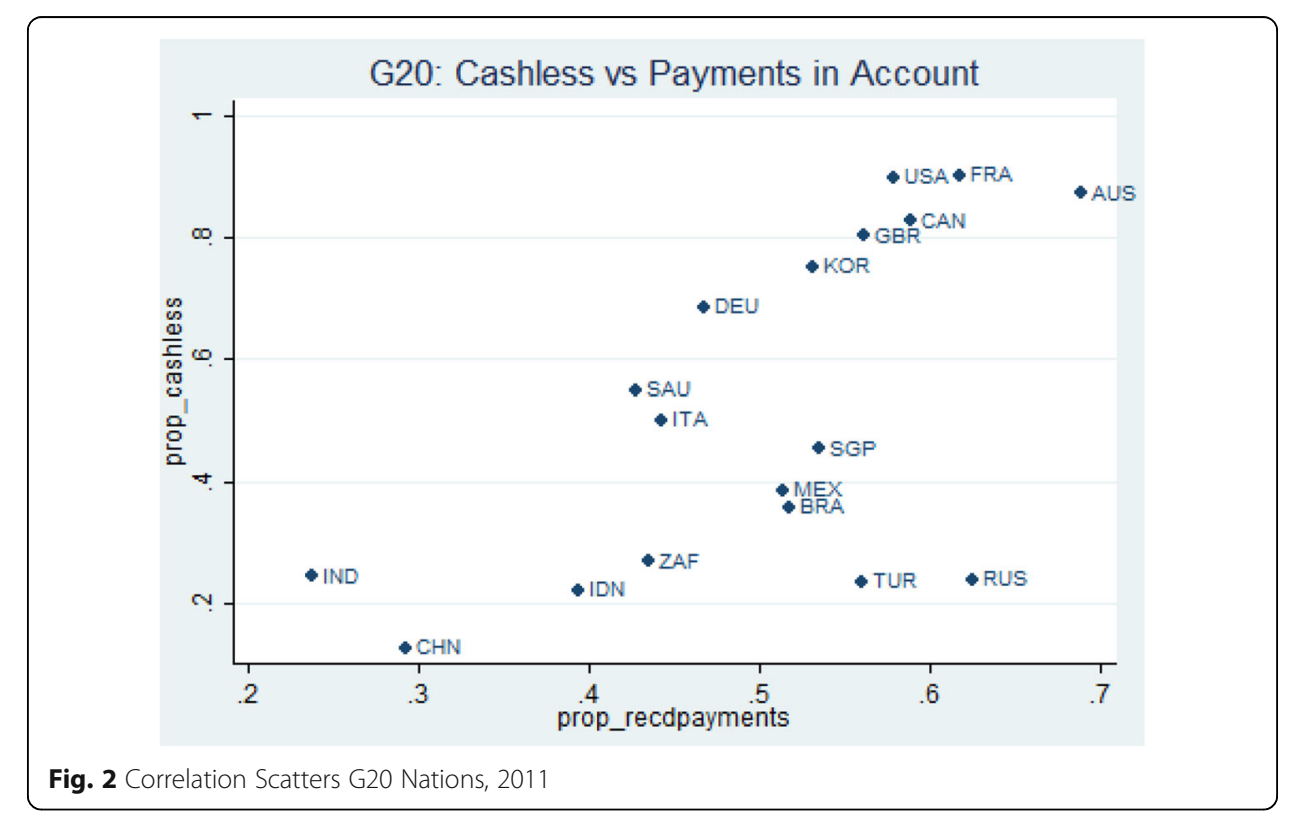


payments in their accounts and of those who make cashless payments. The positive relationship is even more prominent across G20 countries. In Figs. 3 and 4, we present a similar analysis for 2014 .

Figure 3 looks at the correlation scatter plots for all countries, while Fig. 4 looks at the scatter plots for cashless payments versus payments received in accounts for G20 countries. As before, there is a strong positive relationship between the proportion of individuals who received payments in their accounts and make cashless payments. Similar to 2011, there is no positive relationship between high income or high education and cashless payments. Interestingly, India has the lowest proportion of individuals who make cashless payments among all the G20 nations, both in 2011 and in 2014. Globally, a prominent trend is that if accounts see regular payments, chances of cashless payments increase. We inspect this in greater details for India subsequently.

\section{Cashless status in India}

The Findex database in 2014 has 3000 respondents from India. Table 4 presents their key features. The percentages are calculated using population multiplier weights provided in the data set. The population estimate of bank account holders is $53.14 \%$. More than half of these accounts are "dormant," that is, had no activity over the past one year. From the database, a total of $22.25 \%$ of respondents have either a debit card $(22.08 \%)$ or a credit card $(4.17 \%)$. Finally, only $12.41 \%$ of the respondents in the past one year had either used cards, online payments, or other digital platforms to make payments. Among the banked population, this would mean that $23.54 \%$ of individuals have made cashless payments in the past one year.

Given that slightly above half the population is banked, one would naturally expect a lower percentage of individuals using cashless payments. However, cashless payments

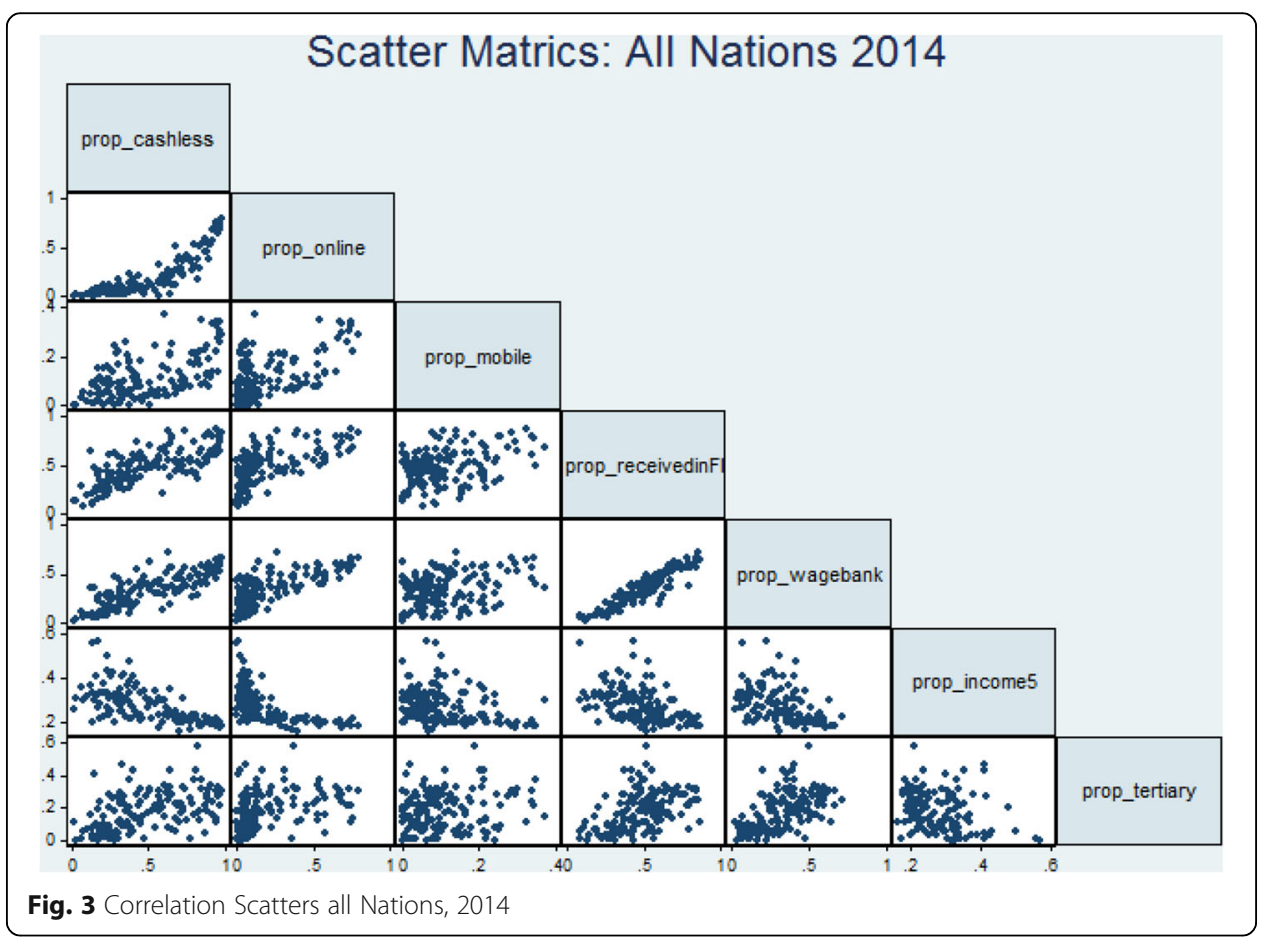




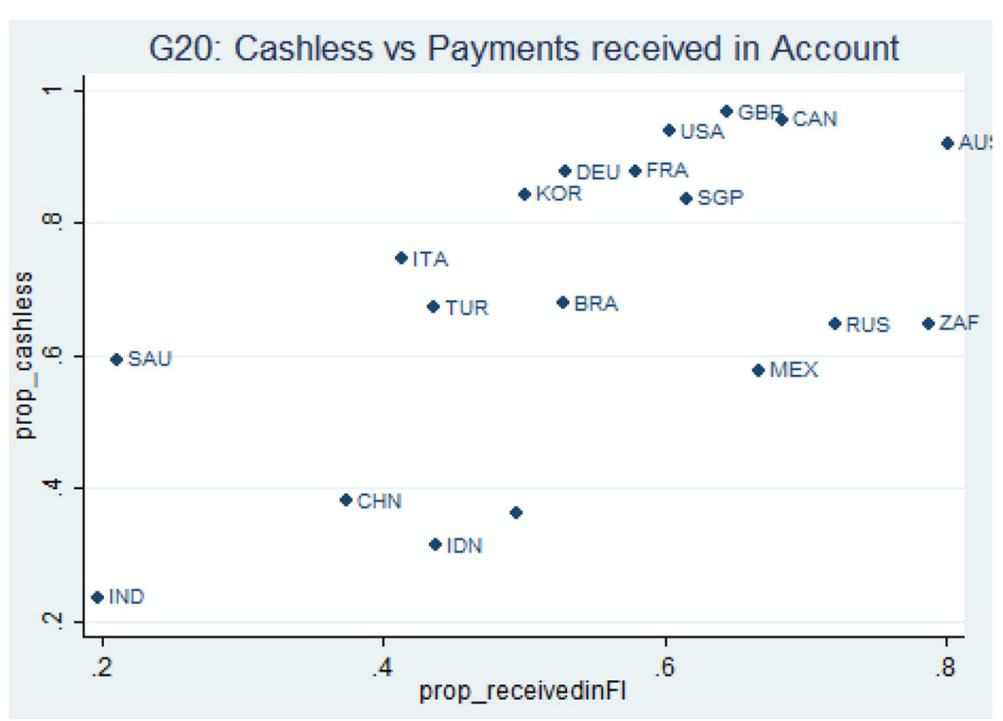

Fig. 4 Correlation Scatters G20 Nations, 2014

have grown considerably in terms of instruments, avenues, transactions, and volumes. While paper-based transactions cleared through checks amounted to INR 85 trillion in 2015, paperless transactions, including retail electronic transactions, such as ECS (electronic clearing system) debits and credits, electronic fund transfer, card transactions, mobile transactions, and prepaid instruments, were around INR 92 trillion in the same period, as per recent RBI data. ${ }^{13}$

We consider monthly time series data on payment systems regarding transaction and monetary volumes by type of instrument, from April 2011 to June $2016 .{ }^{14}$ We ignore earlier periods because details about some of the payment instruments (prepaid cards), as well as transactions (ATM withdrawals), were not available prior to April 2011. Tables 5 and 6 provide an overall summary of how the financial payments have evolved in the past five years. The growth has been impressive, particularly with respect to mobile payments.

Table 4 India: Respondents' Summary

\begin{tabular}{llc}
\hline Item & Description & Percentages \\
\hline Gender & Female & 49.01 \\
School & Primary or less & 53.18 \\
School & Secondary & 42.69 \\
Income & Top 20\% & 19.91 \\
Income & Fourth 20\% & 19.40 \\
Income & Middle 20\% & 21.27 \\
Financial Inclusion & Bank Account & 53.14 \\
Financial Inclusion & Dormant accounts & 28.23 \\
Financial Inclusion & Cards & 22.25 \\
Financial Inclusion & Debit Cards & 22.08 \\
Financial Inclusion & Credit Cards & 4.17 \\
Financial Inclusion & ATM & 16.83 \\
Financial Inclusion & Cashless & 12.41 \\
\hline Data source: http:/wwwits
\end{tabular}

Data source: http://www.worldbank.org/en/programs/globalfindex 
Table 5 Growth of Cashless Transactions in India

\begin{tabular}{lllrrr}
\hline Instruments & Nature & Unit & April, 2011 & June, 2016 & CAGR (\%) \\
\hline Total Cards & No. of Transactions & Mlns & 445.41 & 918.94 & 14.02 \\
Total Cards & Volume transacted & INR Bln & 1170.23 & 2595.31 & 15.42 \\
Pre paid card & No. of Transactions & Mlns & 3.08 & 76.98 & 62.30 \\
Pre paid card & Volume transacted & INR Bln & 4.89 & 53.47 & 46.30 \\
Mobile Banking & No. of Transactions & Mlns & 1.08 & 62.52 & 78.55 \\
Mobile Banking & Volume transacted & INR Bln & 0.76 & 662.72 & 131.05 \\
Credit Card & Outstanding & Mlns & 17.78 & 25.54 & 7.01 \\
Debit Card & Outstanding & Mlns & 230.26 & 688.10 & 21.19 \\
ATM & Numbers & Mlns & 0.08 & 0.22 & 20.24 \\
POS & Numbers & MIns & 0.60 & 1.43 & 16.93 \\
ATM & No. of Transactions & MIns & 399.72 & 724.60 & 11.51 \\
ATM & Money Withdrawn & INR Bln & 1062.61 & 2201.17 & 14.10 \\
POS & No. of Transactions & Mlns & 45.69 & 194.33 & 28.02 \\
POS & Volume transacted & INR Bln & 107.61 & 394.15 & 25.13 \\
Cashless (C) & No. of Transactions & Prop & 0.11 & 0.27 & 17.49 \\
Cashless (C\&M) & No. of Transactions & Prop & 0.11 & 0.32 & 19.91 \\
Cashless (C) & Volume transacted & Prop & 0.09 & 0.15 & 9.71 \\
Cashless (C\&M) & Volume transacted & Prop & 0.10 & 0.34 & 24.14 \\
\hline Data source: RB Pay & Systm Indcars & &
\end{tabular}

Data source: RBI Payment System Indicators http://dbie.rbi.org.in/DBIE/dbie.rbi?site=home

From Table 5, it is evident that, although all types of financial transactions have shown impressive growth, two instruments stand out both in terms of transactions as well as volumes. These are prepaid cards and mobile payments. The prepaid transactions have increased over 25 times and the transaction volume in INR over 10 times, with annual growth rates of $62.30 \%$ and $42.30 \%$, respectively. Mobile transactions during this period have increased almost 60 times and volume transacted in INR almost 900 times. From a share of $91 \%$ of all cashless transactions and $95 \%$ by volume in April 2011, the share of POS payments has dropped to $58 \%$ and $35 \%$, respectively. However, the share of mobile payments increased from $2 \%$ of all transactions and less than $1 \%$ of all cashless transactions by monetary volume in 2011 to $19 \%$ and $60 \%$ in June 2016, respectively. In other words, while all types of cashless payments are on rise, mobile payments have outpaced POS payments in terms of monetary volume and are currently the largest contributor. In Fig. 5, we plot the monetary value transacted via mobile payments, POS, and ATM withdrawals. Although ATM withdrawals outpace the other two in monetary terms, the growth of such withdrawals as well as usage at POS is linear, while that of mobile payments is exponential. Figure 6 establishes the trend clearly: while proportion of cashless card payments increased linearly, the proportion of cashless payments using cards and mobiles did so exponentially. This clearly establishes that the cashless payments in India are fueled by mobile banking.

However, recent monetary growth in India needs to be adjusted for inflation, which often reached double digits. In Table 6, we present the Wholesale Price Index (WPI) adjusted monetary values for 2016. Based on adjusted WPI, the aggregate monetary value has grown by $17.4 \%$, while the growth in per transaction amounts is around $1 \%$. This implies that, while more individuals are making more electronic transactions, 
Table 6 Growth of Cashless Money Values in India

\begin{tabular}{|c|c|c|c|c|c|c|}
\hline Instruments & Nature & Unit & April, 2011 & June, 2016 & $\begin{array}{l}\text { June, } 2016 \\
\text { (WPI adjusted) }\end{array}$ & $\begin{array}{l}\text { CAGR (\%) WPI } \\
\text { Adjusted }\end{array}$ \\
\hline Total Cards & Volume transacted & INR BIn & 1170.2 & 2595.3 & 2293.6 & 12.8 \\
\hline Total Cards & Amt per transaction & INR & 2627.3 & 2824.2 & 2495.9 & -1 \\
\hline Credit Card & Volume transacted & INR Bln & 71.5 & 242.4 & 214.2 & 20.9 \\
\hline Credit Card & Amt per transaction & INR & 3056.4 & 3152.6 & 2786 & -1.8 \\
\hline Credit Card & Money Withdrawn & INR BIn & 1 & 2.9 & 2.5 & 18.4 \\
\hline Credit Card & Amt per transaction & INR & 5647.1 & 4847.5 & 4283.9 & -5.3 \\
\hline Credit Card & POS value spent & INR BIn & 70.6 & 239.5 & 211.7 & 20.9 \\
\hline Credit Card & Amt per transaction & INR & 3037 & 3139.4 & 2774.5 & -1.7 \\
\hline Debit Card & Volume transacted & INR Bln & 1098.7 & 2352.9 & 2079.4 & 12.2 \\
\hline Debit Card & Amt per transaction & INR & 2603.5 & 2794.3 & 2469.4 & -1 \\
\hline Debit Card & Money Withdrawn & INR Bln & 1061.7 & 2198.3 & 1942.7 & 11.5 \\
\hline Debit Card & Amt per transaction & INR & 2657.1 & 3036.3 & 2683.3 & 0.2 \\
\hline Debit Card & POS value spent & INR BIn & 37.1 & 154.6 & 136.6 & 24.9 \\
\hline Debit Card & Amt per transaction & INR & 1650 & 1309.9 & 1157.6 & -6.8 \\
\hline Pre paid card & Volume transacted & INR BIn & 4.9 & 53.5 & 47.3 & 43.2 \\
\hline Pre paid card & Amt per transaction & INR & 1587.7 & 694.6 & 613.8 & -18.1 \\
\hline Mobile Banking & Volume transacted & INR BIn & 0.8 & 662.7 & 585.7 & 126.6 \\
\hline Mobile Banking & Amt per transaction & INR & 703.7 & 10600.1 & 9367.7 & 49.3 \\
\hline ATM & Money Withdrawn & INR BIn & 1062.6 & 2201.2 & 1945.3 & 11.5 \\
\hline ATM & Amt per transaction & INR & 2658.4 & 3037.8 & 2684.6 & 0.2 \\
\hline POS & Volume transacted & INR BIn & 107.6 & 394.2 & 348.3 & 22.4 \\
\hline POS & Amt per transaction & INR & 2355.2 & 2028.3 & 1792.4 & -5.2 \\
\hline All Instruments & Volume transacted & INR BIn & 1175.9 & 3311.5 & 2926.5 & 17.4 \\
\hline All Instruments & Amt per transaction & INR & 2615.6 & 3128.7 & 2764.9 & 1.1 \\
\hline
\end{tabular}

Data source: RBI Payment System Indicators http://dbie.rbi.org.in/DBIE/dbie.rbi?site=home and fWPI from http://www.eaindustry.nic.in/download_data_0405.asp

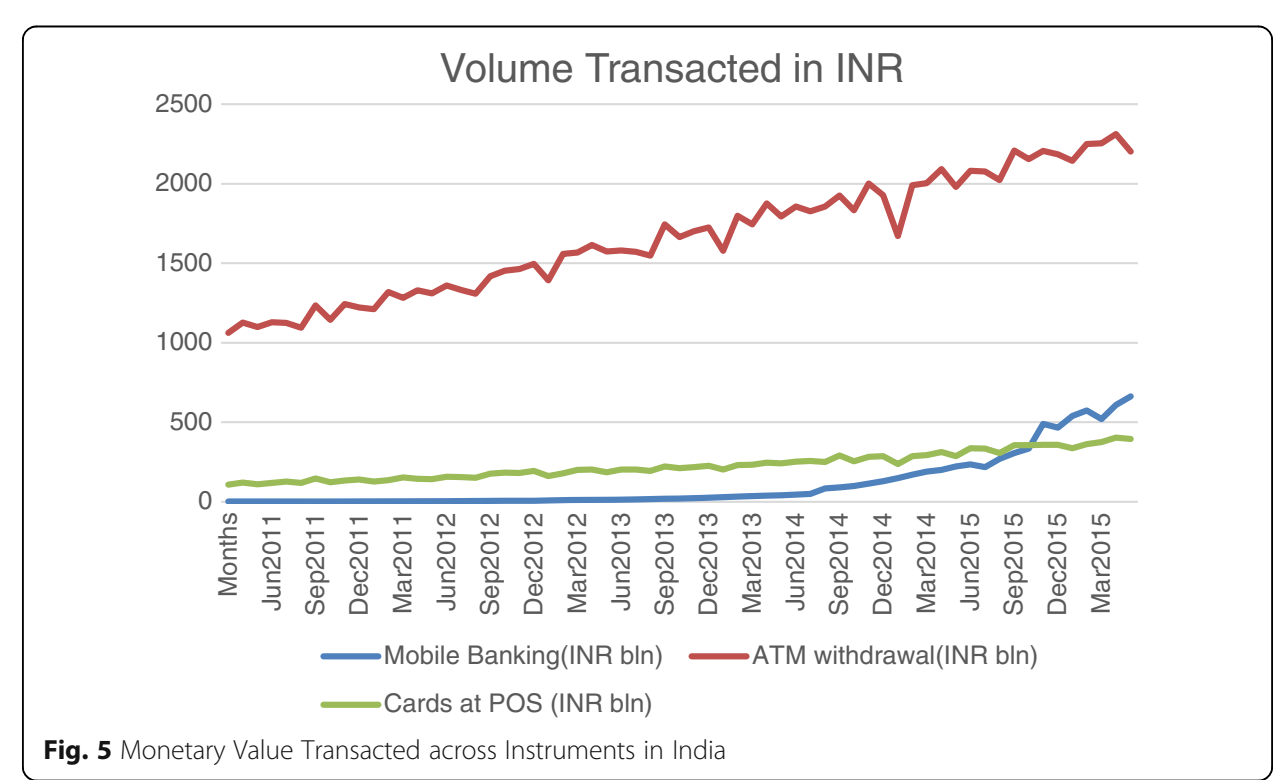




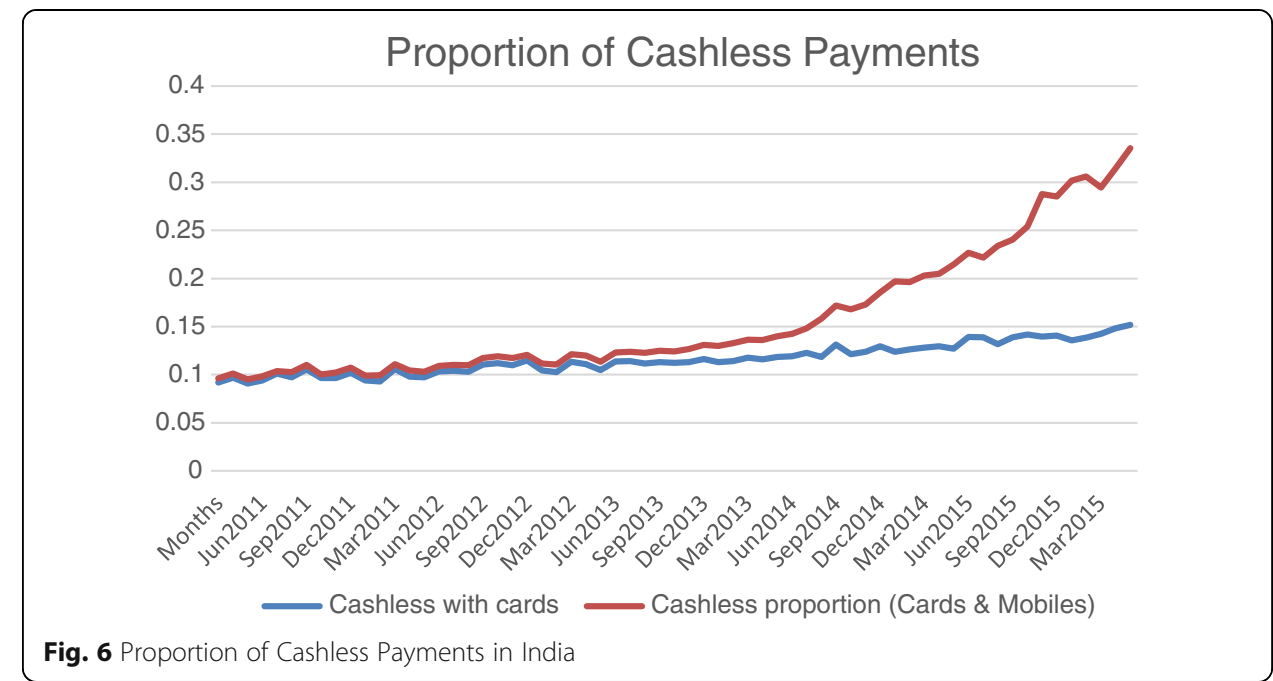

the amounts they typically spend per transaction are stagnant. In fact, several show negative growth rates. The amounts withdrawn from ATMs per transaction have a positive growth rate $(0.2 \%)$, while the amount per transaction at POS have a negative growth rate $(-5.2 \%)$ This clearly establishes that demand for currency in the system has not decreased, but other attractive payment avenues have compensated the demand for cash. The aggregate monetary transaction values, as well as per transaction amount, have grown significantly with mobile banking $(126.6 \%$ and $49.3 \%$, respectively). In comparison, the growth rate in India has outpaced that of the EU in the last two years (Table 1). First, for India, the number of ATM transactions as well as the monetary volume withdrawn has increased, whereas it has decreased in the EU, indicating a substitution of cash for the latter. However, the growth rates in terms of transactions, ATMs, or POS machines in India outweigh those of the EU. This is partly owing to the low base effect in India, but also due to systemic reasons. Second, the growth of cashless payments in India is primarily driven by mobile payments.

BCG (2016) estimates that the digital payments industry in India will grow 10 times, reaching USD 500 billion by 2020 and contribute 15\% to the GDP. They attribute this growth to (a) growing base of smart phone connections, which is expected to grow to 540 million by 2020; (b) enabling regulatory requirements (low Know Your Customers (KYC) requirements) for small digital payments; and (c) enhanced customer satisfaction with digital payments (especially with the e-commerce firms in India).

The government has also made it increasingly easier to pay bills digitally. Similar findings are reported in Deloitte (2016). It appears that the current infrastructure in India is far more conducive for mobile and online payments than is using cards at POS. Mobile and online payments substitute POS, primarily because there is almost a negative cost associated with using online cashless instruments (frequent discounts and loyalty points along with no time cost) as opposed POS payments. In the next section, we explore the factors that explain cashless payments in India. We also empirically test the factors that explain cashless payments among individuals in India. 


\section{Empirical model of household decisions}

\section{Testing the theoretical model}

We develop simple logistic regression models to predict what explains an individual making cashless payments. The predicted variable in all four models is the probability that an individual has made a cashless payment in the past one year. The coefficients are the odds-ratio. We control for gender, maximum education attained, and income. Income is either categorical and coded as $1-5$, where 1 denotes the lowest $20 \%$ and 5 denotes the richest $20 \%$ (models 1,3 , and 4 ) or is treated as separate dummy variable (model 2). The model specification is in tune with the theoretical framework developed in section 3.

We estimate

$$
\begin{aligned}
& F\left(\frac{p_{i}}{1-p_{i}}\right)=\beta_{0}+\beta_{1} \cdot \text { Male }_{i}+\beta_{2} \text { Age }_{i}+\beta_{3} \text { Secondary }_{i}+\beta_{4} \text { Tertiary }_{i}
\end{aligned}
$$

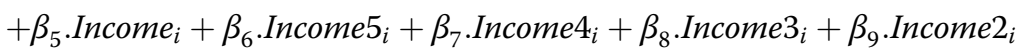

$$
\begin{aligned}
& +\beta_{10} \text { Wagebank }_{i}+\beta_{11} \text { Wage }_{i}+\beta_{12} \text { Dormant }_{i}+\beta_{13} \text { ATM }_{i}
\end{aligned}
$$

In model 1 we set, $\beta_{6}=\beta_{7}=\beta_{8}=\beta_{9}=0$

Model 1 controls income as a continuous variable.

In model 2 we set, $\beta_{5}=0$

Model 2 uses income quintiles as dummies

In model 3 we set, $\beta_{6}=\beta_{7}=\beta_{8}=\beta_{9}=\beta_{11}=0$

Model 3 controls income as quintiles as well as whether the individual receives regular income (wages)

In model 4 we set, $\beta_{6}=\beta_{7}=\beta_{8}=\beta_{9}=\beta_{10}=0$

Model 4 omits whether an individual receives wages in his/her account or not.

Based on our theoretical model, we should expect a positive impact of higher income, as well convenience (measure whether payments are credited in the accounts-Wagebank) on cashless transactions. Thus, we expect the $\beta_{5}$ coefficient to be higher than the ones in models 1,3 , and 4 , the coefficients $\beta_{6}, \beta_{7}, \beta_{8}, \beta_{9}$ to be higher than the ones in model 2 , and the $\beta_{10}$ coefficient higher than the ones in models $1-3$. We tried alternate specifications replacing 'payments received in accounts' in place of 'wages in accounts' but the results were similar. Table 7 presents the results of the logistic regressions. The models have sufficient classification power (high Receiver Operating Curves (ROC), specificity, as well as sensitivity). There are two factors that explain the probability of an individual incurring cashless expenses. One is exogenous to the respondent's usage of financial instruments, while the other is not. The variable "Wagebank" indicates whether the respondents receive wages in their accounts. This is largely exogenous to their decision-making, although the types of economic activities they are engaged in suggests self-selection. The other is their decision to use ATMs or keep the accounts "dormant," which reflects endogenous choices. We find that both these factors are significant. Interestingly, whether the respondent has regular income or not (variable "Wage") does not influence his/her decision to make cashless payments. What influences his/her decision is whether there is an inflow of wages or payments in the account ('Wagebank" is significant). This follows the global pattern, as well as our theoretical model presented earlier. 
Table 7 Predicting Cashless Payments

\begin{tabular}{lllll}
\hline & Model 1 & Model 2 & Model 3 & Model 4 \\
\hline Male & $1.980^{\mathrm{a}}$ & $2.008^{\mathrm{a}}$ & $1.908^{\mathrm{a}}$ & $1.911^{\mathrm{a}}$ \\
Age & 1.001 & 1.000 & 1.002 & 1.002 \\
Secondary & 1.141 & 1.104 & 1.143 & 1.147 \\
Tertiary & 1.140 & 1.054 & 1.143 & 1.209 \\
Income & $1.266^{\mathrm{a}}$ & & $1.263^{\mathrm{a}}$ & \\
Income5 & & $1.262^{\mathrm{a}}$ & & \\
Income4 & & 1.099 & & \\
Income3 & & 1.118 & & 1.002 \\
Income 2 & $1.424^{\mathrm{b}}$ & & $0.622^{\mathrm{a}}$ \\
Wagebank & $2.378^{\mathrm{a}}$ & $1.725^{\mathrm{b}}$ & $15.01^{\mathrm{a}}$ \\
Wage & $2.284^{\mathrm{a}}$ & 0.731 & & 1677 \\
Dormant & 0.712 & $0.643^{\mathrm{a}}$ & $0.644^{\mathrm{a}}$ & 0.339 \\
ATM & $0.632^{\mathrm{a}}$ & $14.94^{\mathrm{a}}$ & $14.82^{\mathrm{a}}$ & $66.84 \%$ \\
No of Obs & $14.61^{\mathrm{a}}$ & 1677 & 1677 & $87.55 \%$ \\
Pseudo R & 1677 & 0.35 & 0.341 & $82.70 \%$ \\
Specificity & 0.342 & $65.31 \%$ & $67.09 \%$ & 0.870 \\
Sensitivity & $66.58 \%$ & $88.95 \%$ & $87.94 \%$ & 0.871 \\
Overall & $87.20 \%$ & $83.42 \%$ & & \\
ROC & $82.77 \%$ & 0.877 & & \\
\hline
\end{tabular}

a denote significant at $99 \%{ }^{\text {b }}$ denote significant at $95 \%$

Dependent variable is cashless (binary). All explanatory variables are binary except "Income". Income $=k ; k=1,2 ., .5$ if the respondent belongs to the " $k$ highest" $20 \%$ income bracket

Note that the decision to use cashless instruments is 14 times as much for individuals who have used ATMs as compared to those who have not. While from the above database one cannot identify "what makes an individual use the ATM," one can assign the possible advantages of using the ATM and the enablers. Convenience in the form of saving time (vis-á-vis withdrawing money from tellers), even if it involves inter-bank transfer fees, is the primary reason. There are two reasons why "Wagebank" is significant. Given that the payment is already in the bank account, this allows the individuals to use cashless payments more frequently. Further, given that such transactions have digital footprints, it may incentivize some individuals to make digital payments. Both these factors make amounts credited to the account convenient for using cashless transactions. We explore the nature of this argument in the following section.

\section{Household decisions}

The survey conducted by Mukhopadhyay and Rath (2011) was across 2246 households and 700 enterprises, in eight cities in India. Although the survey consisted both rural as well as urban households, in this paper we will only consider the responses from the urban households (2465 in all). The data were collected in 2010.

The household survey was based on the socio-economic classification (SEC), where the enterprises represented the following sectors: grocery, clothing and footwear, education, medical shops, nursing homes and hospitals, cab service providers, truck owners, 
mobile service providers, IT and ITES providers, and consumer durables. The survey was conducted across the four metropolitan areas of Delhi, Mumbai, Kolkata, and Bengaluru along with four tier I cities-Kanpur, Surat, Jaipur, and Vishakhapatnam. The SEC classification is presented in Table 8.

Table 9 presents item-wise cashless spending. The data estimate that $12.34 \%$ of households made cashless payments in India. This is also close to the estimates from the Findex data (2011). If one classifies households across three categories based on frequency of cashless usage-low (households making cashless transactions two or more items), moderate (households making cashless transactions five or more items), and high (households making cashless transactions 10 or more items) - one finds that $2.5 \%$ of households are in the low category, $0.74 \%$ in the moderate, and only $0.16 \%$ in the high category. As a percentage of all those households who make cashless transactions, the numbers are $20.21 \%, 6.03 \%$, and $1.31 \%$, respectively. More than $70 \%$ of the households make cashless payments through only one item. This clearly establishes that, although households are exposed to cashless instruments, there are not many items convenient for making such payments. As such, an item-wise breakup of cashless payments presents an interesting scenario.

Some of the most prominent items (each of them having at least 3\% cashless expenditure) are: rent, clothing and footwear, electricity, telephone and mobile bill payments, education, and conveyance. What is common to these items is the fact that these expenses are usually reimbursed by the employer to its employees. Most work contracts have such incentives built in. There are explicit reimbursements for rent, communications (usually telephone bills), conveyance allowances, as well as educational expenses. This means that keeping records of financial transactions for these items are in the interest of the households to claim reimbursements. Given that non-cash expenditure keeps "digital footprints," it makes payments using non-cash instruments more likely.

Table 8 Urban SEC

\begin{tabular}{|c|c|c|c|c|c|c|c|}
\hline \multirow[t]{2}{*}{ Occupation } & \multicolumn{7}{|c|}{ Education } \\
\hline & Illiterate & $\begin{array}{l}\text { Less than } 4 \\
\text { years in school }\end{array}$ & $\begin{array}{l}5-9 \text { years } \\
\text { of school }\end{array}$ & $\begin{array}{l}\text { School } \\
\text { certificate }\end{array}$ & $\begin{array}{l}\text { Some } \\
\text { college }\end{array}$ & Graduate & $\begin{array}{l}\text { Post- } \\
\text { graduate }\end{array}$ \\
\hline Skilled & E2 & E1 & $\mathrm{D}$ & C & $C$ & B2 & B2 \\
\hline Unskilled & E2 & E2 & E1 & $\mathrm{D}$ & $D$ & $\mathrm{D}$ & $\mathrm{D}$ \\
\hline Shop owner & $D$ & $D$ & C & B2 & B2 & $\mathrm{A} 2$ & $\mathrm{~A} 2$ \\
\hline Petty trader & E2 & $\mathrm{D}$ & $\mathrm{D}$ & C & C & B2 & B2 \\
\hline $\begin{array}{l}\text { Employer of above } \\
10 \text { persons }\end{array}$ & B1 & B1 & $\mathrm{A} 2$ & $\mathrm{~A} 2$ & $\mathrm{~A} 1$ & $\mathrm{~A} 1$ & $\mathrm{~A} 1$ \\
\hline $\begin{array}{l}\text { Employer of below } \\
10 \text { persons }\end{array}$ & C & B2 & B2 & B1 & $\mathrm{A} 2$ & $\mathrm{~A} 1$ & $\mathrm{~A} 1$ \\
\hline Employer of none & D & C & B2 & B1 & $\mathrm{A} 2$ & $\mathrm{~A} 1$ & $\mathrm{~A} 1$ \\
\hline Clerk & $\mathrm{D}$ & $\mathrm{D}$ & $\mathrm{D}$ & C & B2 & B1 & B1 \\
\hline Supervisor & $\mathrm{D}$ & $\mathrm{D}$ & C & C & B2 & B1 & $\mathrm{A} 2$ \\
\hline Professional & $\mathrm{D}$ & $\mathrm{D}$ & $\mathrm{D}$ & B2 & B1 & $\mathrm{A} 2$ & $\mathrm{~A} 1$ \\
\hline Senior executive & B1 & B1 & B1 & B1 & $\mathrm{A} 2$ & $\mathrm{~A} 1$ & $\mathrm{~A} 1$ \\
\hline Junior executive & C & C & C & B2 & B1 & $\mathrm{A} 2$ & $\mathrm{~A} 2$ \\
\hline
\end{tabular}

Data source: Mukhopadhyay and Rath (2011) 
Table 9 Household-Percentage of Cashless

\begin{tabular}{lll}
\hline Items & Percentage (households) & Percentage (expenditure) \\
\hline Cereals & 1.26 & 2.48 \\
Milk and Milk Products & 0.65 & 0.68 \\
Edible oils & 0.99 & 1.47 \\
Eggs, Fish and Meat & 1.22 & 1.13 \\
Vegetables and Fruits & 0.6 & 1 \\
Sugar and Salt & 0.81 & 1.56 \\
Beverages and Refreshments & 0.78 & $\mathbf{7 . 1 4}$ \\
Pan, Tobacco and Intoxicants & 0.24 & 0.28 \\
Processed Foods & 0.59 & 1.48 \\
Electricity & 1.98 & $\mathbf{3 . 2 7}$ \\
LPG and Other Fuels & 1.27 & 2.18 \\
Entertainment and Related Expenses & 1.1 & $\mathbf{3 . 4 6}$ \\
Other Consumer Services (not conveyance) & 1.2 & 2.21 \\
Domestic Servant, Cook and Sweeper & 0.65 & 2.55 \\
Barber, Beautician, Tailor & 0.64 & 1.49 \\
Telephone and Mobile Charges & $\mathbf{1 . 5 5}$ & $\mathbf{3 . 6 3}$ \\
Conveyance & $\mathbf{1 . 4 8}$ & $\mathbf{5 . 7 8}$ \\
Rent & $\mathbf{3 . 1 3}$ & $\mathbf{9 . 8 1}$ \\
Durable Goods & $\mathbf{4 . 2 3}$ & $\mathbf{5 . 2 5}$ \\
Clothing and Footwear & $\mathbf{3 . 5 2}$ & $\mathbf{5 . 1 1}$ \\
Education & $\mathbf{3 . 1 3}$ & $\mathbf{3 . 0 7}$ \\
Medical, Institutional & $\mathbf{1 . 5 5}$ & 1.03 \\
Medical, Non-institutional & 1 & 1.82 \\
Personal care, Toiletries and Sundry & $\mathbf{1 . 5 4}$ & $\mathbf{4 . 3 2}$ \\
Rail and Air Travel & 1.11 & 2.81 \\
Total & 12.34 & 2.92 \\
\hline & &
\end{tabular}

*The percentages for the top ten consumption items are boldfaced

However, it is not the built-in incentives alone that promote cashless expenditures. Apart from incentives to keep financial records, whether the transaction involves cash or not depends on whether the seller has the necessary infrastructure to accept noncash payments. This is the reason why "Wagebank" plays such a prominent role. In Table 10, we explore the main reasons that discourage households from making cashless payments.

Unsurprisingly, the main reason for not using cashless transactions is that the seller does not accept them. This is also confirmed by the one-way ANOVA table (Fig. 7).

The seller's refusal to accept cashless payments could be either because the seller has not installed a POS or may have installed the POS, but is unwilling to accept cashless transactions. These are the key reasons identified in our theoretical model. The reluctance to join the cashless network is partly because of the joining fee, low connectivity, as well as tax avoidance. Our analysis of micro-level data suggest that, while cashless payments through POS may be a common feature elsewhere, in India, it is mobile payments that dominate. Mobile payments are expected to grow to 220 million by 2020 , 
Table 10 Household -Reasons for not using cashless payments (in percentages)

\begin{tabular}{|c|c|c|c|c|c|}
\hline Items & Not accept & Small & Extra charges & Security & Not aware \\
\hline $\begin{array}{l}\text { Cereals \& cereal products, pulses \& their } \\
\text { products \& spices }\end{array}$ & 47.98 & 13.11 & 6.15 & 9.75 & 14.4 \\
\hline Milk \& milk products & 46.16 & 19.47 & 5.22 & 8.12 & 13.38 \\
\hline Edible oil & 43.63 & 21.31 & 6.47 & 6.81 & 13.99 \\
\hline Egg, fish and meat & 49.45 & 18.65 & 6.32 & 8.71 & 14.79 \\
\hline Vegetables \& fruits & 45.65 & 18.52 & 6.25 & 7.71 & 14.09 \\
\hline Sugar \& salt & 41.52 & 24.15 & 5.68 & 7.15 & 14.11 \\
\hline Beverages \& refreshments & 40.97 & 24.65 & 6.41 & 7.62 & 14.22 \\
\hline Pan, tobacco and intoxicant & 38.25 & 22.17 & 6.8 & 11.84 & 14.49 \\
\hline Processed food & 34.9 & 26.85 & 8.22 & 10.76 & 14.41 \\
\hline Electricity & 30.96 & 27.17 & 8.69 & 10.31 & 14.77 \\
\hline LPG and other Fuels & 36.02 & 25.32 & 8.64 & 7.66 & 14.72 \\
\hline Entertainment \& related expenditure & 37.68 & 24.59 & 7.31 & 8.91 & 16.17 \\
\hline Other consumer services excl. Conveyance & 41.65 & 18.71 & 8.05 & 10.4 & 16.57 \\
\hline Domestic servant/cook \& Sweeper & 47.04 & 16.54 & 7.37 & 12.74 & 11.63 \\
\hline Barber, beautician, tailor etc & 43.08 & 23.58 & 6.24 & 7.03 & 13.37 \\
\hline Telephone/mobile charges & 36.7 & 24.47 & 7.65 & 9.06 & 14.16 \\
\hline Conveyance & 41.38 & 21.87 & 7.02 & 8.78 & 14.49 \\
\hline Rent & 45 & 19.02 & 6.95 & 12.32 & 13.05 \\
\hline Durable goods & 29.63 & 14.35 & 13.89 & 20.83 & 13.89 \\
\hline Clothing \& footwear & 28.52 & 15.46 & 13.56 & 18.4 & 15.82 \\
\hline Education & 31.24 & 14.75 & 12.88 & 16.58 & 16.58 \\
\hline Medical - institutional & 27.95 & 16.1 & 15.83 & 12.98 & 19.82 \\
\hline Medical (non-institutional) & 30.25 & 23.19 & 10.33 & 15.5 & 15.56 \\
\hline Personal care, toilet and sundry articles & 38.07 & 21.15 & 8.83 & 10.89 & 14.42 \\
\hline Conveyance-Air fare \&Railways & 29.38 & 20.53 & 10.21 & 16.34 & 19.12 \\
\hline Averages & 38.52 & 20.87 & 8.44 & 11.09 & 14.63 \\
\hline
\end{tabular}

i.e., a $1000 \%$ growth. Correspondingly, the e-commerce volume of USD 2.9 billion in 2013 is expected to grow to USD 106 billion by $2020 .{ }^{15}$ Mobile and online payments substitute POS primarily because there is almost a negative cost with using online cashless instruments (frequent discounts and loyalty points along with no time cost) as opposed to POS payments.

\section{Conclusion}

This paper analyzes the key steps in making India gradually migrate towards a cashless economy. In doing so, it estimates the amount of cashless transactions prevalent in India,

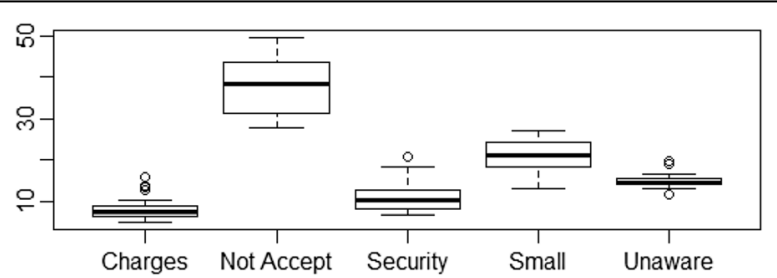

Fig. 7 Household Reasons for not using Cashless 
and identifies what is functioning and what requires improvements. This paper is also the first comprehensive attempt to look at cashless payments from the perspective of instruments (cards versus mobile payments) and micro units (individuals and households). We present a theoretical model of payment decisions by consumers and sellers. These decisions are influenced by the convenience of cashless transactions weighed against the temptation to evade taxes. Given that the cashless economy involves network effects, certain enablers are identified. We subsequently tested our model using Global Findex data, as well as household and enterprise surveys. Some of our key estimates are:

a) Significantly higher proportion of individuals make cashless payments now (12.61\% in 2014 as compared to $3.47 \%$ in 2011);

b) The number and the monetary value of cashless transactions have a CAGR of $19.91 \%$ and $24.14 \%$, respectively;

c) Most growth in cashless payments has been through mobile payments.

Interestingly, we found that as more payments are directly credited to the account, cashless payments increase significantly. Therefore, while in the short run a positive "shock" towards developing a critical network is important, in the steady-state equilibrium, cashless transactions increase only if accounts have steady inflows.

Our analysis identifies policy directions for India as follows.

Awareness about the advantages of cashless payments: A concerted effort to make individuals aware of the advantages of cashless payments is the starting point. Incentivize payments into accounts: The positive relationship between regular inflows into accounts and cashless payments is strong. However, given that less than $10 \%$ of the labor force is in the organized sector, few will have a steady flow into their accounts. Apart from the G2P payments, which are now being directly credited to accounts, an incentive (in terms of tax rebates) to individuals who make payments/ remittances in accounts will see a major boost.

Removal of e-payment costs: Merchant Discount Rates and convenience charges associated with e-payments must be reduced.

Mobile banking as an extension of banking: Although mobile payments dominate the cashless scenario, loading the mobile wallet is currently allowed almost entirely through bank accounts. What could be more effective is allowing individuals to directly deposit cash in the mobile wallet. Indeed, if this was allowed in the current demonetization exercise, it would have tremendous short- and long-term gains.

There are many interesting research problems to be considered. For India, the roadmap of how the cashless payments infrastructure can promote financial inclusion is perhaps the most exciting issue to be addressed. Further, with the newly enacted GST, linking cashless payments to ensure a more efficient collection of taxes would be an interesting policy intervention. The recent demonetization of high valued currency presents a new scenario. With available data, one needs to see the impact of this sudden shock on cashless payments. 


\section{Endnotes}

${ }^{1}$ There are alternate viewpoints to cashless being a good outcome. This mainly stems from the fact that cashless payments leave digital footprints, which may be exploited by not so benevolent Governments. https://www.theguardian.com/money/commentisfree/ 2016/mar/21/fear-cashless-world-contactless

${ }^{2}$ http://dbie.rbi.org.in/DBIE/dbie.rbi?site=publications

${ }^{3}$ The latest demonetization drive in India estimates a INR 10,000 crore cost to replace the INR 500 and INR 1,000 notes. These notes make up $85 \%$ of the total monetary value in circulation.

${ }^{4}$ http://www.iamai.in/research/reports_details/423

${ }^{5}$ The estimates according to the Finance Minister is INR 45,00,000 crores! See http:// www.asianage.com/india/indian-black-money-estimated-around-rs-45-lakh-crores-076

${ }^{6} \mathrm{http} / /$ www.thehindu.com/news/national/black-economy-now-amounts-to-75-ofgdp/article6278286.ece?homepage=true\#lb?ref=infograph/0/, http://www.nytimes.com/ 2014/06/26/world/asia/indias-underground-economy.html?_r=0, http://www.ibtimes.com/india-has-second-highest-rate-shadow-businesses-world-study-1590949

${ }^{7}$ http://www.heritage.org/index/explore?view=by-variables. Among the BRICS nation, Russia (34.8), Brazil (33.4), South Africa (24.7) and China (19.4) all exceed India.

${ }^{8} \mathrm{http}: / /$ www.dnaindia.com/money/report-income-tax-assessees-rise-to-517-crore-in2014-15-i-t-department-2208052

${ }^{9}$ http://www.pmjdy.gov.in/account

${ }^{10} \mathrm{http}: / /$ pdscvc.nic.in/report\%20on\%20computersisation\%20of\%20PDS.htm.

${ }^{11}$ However, note that the indirect tax, $t_{x}$ must be such that A.2 is satisfied.

${ }^{12}$ The Global Findex data base can be accessed at: http://www.worldbank.org/en/programs/globalfindex

${ }^{13} \mathrm{http} / / /$ articles.economictimes.indiatimes.com/2015-05-25/news/62624723_1_transactions-lakh-crore-payment-bank-licence

${ }^{14}$ http://dbie.rbi.org.in/DBIE/dbie.rbi?site=home

${ }^{15}$ https://www2.deloitte.com/content/dam/Deloitte/in/Documents/technology-mediatelecommunications/in-tmt-e-commerce-in-india-noexp.pdf

\section{Acknowledgements}

The author wishes to acknowledge the editorial office, the anonymous referees of this journal. Further, the paper benefitted immensely from the invaluable comments and suggestions made by seminar participants at India Development Foundation, Great Lakes Institute of Management, University of Ulm and Indian Finance Conference 2014. All errors-typos or otherwise, is mine

\section{Author's contribution}

The author had lead a team that conducted the household survey in 2010. Subsequently, all data collection, its analysis as well as developing the theoretical model was done by him.

\section{Competing interests}

The author declares that he has no competing interests.

Received: 30 November 2015 Accepted: 1 December 2016

Published online: 13 December 2016

References

Baxter WF (1983) Bank Interchange of Transactional Paper: Legal and Economic Perspectives". J Law Econ 26(3):541-588 BCG (2016) "Digital Pyments 2020". http://image-src.bcg.com/BCG_COM/BCG-Google\%20Digital\%20Payments\%202020July\%202016_tcm21-39245.pdf

Bhattacharya K, Singh S (2015) "Does easy availability of cash effect corruption? Evidence from panel of countries", MPRA paper number 65934. https://mpra.ub.uni-muenchen.de/65934/1/MPRA_paper_65934.pdf

Bolt W, Humphrey DB, Uittenbogaard R (2008) Transaction pricing and the adoption of electronic payments: A crosscountry comparison". Int J Central Bank 4(1):89-123 
Das A, Agarwal R (2010) "Cashless Payment System in India- A Roadmap", Technical report, IIT Bombay. http://dspace. library.iitb.ac.in/jspui/handle/10054/1732

Deloitte (2016) "e-Commerece in India: A Game Changer". https://www2.deloitte.com/content/dam/Deloitte/in/ Documents/technology-media-telecommunications/in-tmt-e-commerce-in-india-noexp.pdf

Demirguc-Kunt A, Klapper L (2012) "Measuring Financial Inclusion: The Global Findex Database." World Bank Policy Research Working Paper No. 6025

Demirguc-Kunt A, Klapper L, Singer D, Van Oudheusden P (2014) "The Global Findex Database 2014 Measuring Financial Inclusion around the World", World Bank Policy Research Working Paper 7255

Galbraith JW, Tkacz G (2015) "Nowcasting GDP with Electronic Payments Data", ECB Statistics Paper Series, \#10. https:// www.ecb.europa.eu/pub/pdf/scpsps/ecbsp10.en.pdf

Gangopadhyay S (2009) How can Technology Facilitate Financial Inclusion in India? A Discussion Paper". Rev Mark Integr 1(2):223-256

Hasan I, De Renzis T, Schmiedel H (2013) "Retail Payments and the Real Economy" ECB Working Paper Series, (1572). https://www.ecb.europa.eu/pub/pdf/scpwps/ecbwp1572.pdf?0568b27871896eb01f54b0c4c40a8f63

Kearney AT, Friedrich Schneider F (2011) "The shadow economy in Europe, 2011". https://www.atkearney.de/ documents/856314/1214702/BIP_The_Shadow_Economy_in_Europe.pdf/cd3277da-74c3-4a35-9ac4-97f7a0e93518

Kearney AT, Friedrich Schneider F (2013) "The shadow economy in Europe, 2013". https://www.atkearney.com/ documents/10192/1743816/The+Shadow+Economy+in+Europe+2013.pdf

Kruger M, Seiz F (2014) Costs and Benefits of Cash and Cashless Instruments. https://www.bundesbank.de/Redaktion/ EN/Downloads/Publications/Studies/costs_and_benefits_of_cash_2014.pdf?_blob=publicationFile

Madzharova B (2014) "The impact of cash and card transactions on VAT collection efficiency". https://www.bundesbank. de/Redaktion/EN/Downloads/Tasks/Cash_management/Conferences/2014_09_16_the_impact_of_cash_and_card_ transactions_on_vat_collection_efficiency.pdf?blob=publicationFile

Moody's Analytics (2013) "The Impact of Electronic Payments on Economic Growth". https://usa.visa.com/dam/VCOM/ download/corporate/media/moodys-economy-white-paper-feb-2013.pdf

Mukhopadhyay B, Rath S (2011) Role of MFIs in Financial Inclusion. Rev Mark Integr 3(3):243-286

Rochet JC, Tirole J (2003) "Platform Competition in Two Sided Markets'. http://www.rchss.sinica.edu.tw/cibs/pdf/ RochetTirole3.pdf

Rochet JC, Tirole J (2004) Two Sided Markets: An Overview. RAND J Econ 37:645-667, No. 3 (Autumn, 2006)

Schneider F (2006) "Shadow Economies and Corruption All Over the World: What do we Really Know?". http://ftp.iza. org/dp2315.pdf

Shy O, Tarakka J (2002) The Market for Electronic Cash Cards. J Money Credit Bank 34(2):299-324

World Payments Report (2015). https://www.fr.capgemini-consulting.com/resource-file-access/resource/pdf/world_ payments_report_2015_vfinal.pdf

Wright J (2003) Optimal Card Payment Systems. Eur Econ Rev 47:587-612

Zandi M, Singh V, Irving J (2013) "The Impact of Electronic Payments on Eonomic Growth". https://usa.visa.com/dam/ VCOM/download/corporate/media/moodys-economy-white-paper-feb-2013.pdf

\section{Submit your manuscript to a SpringerOpen ${ }^{\circ}$ journal and benefit from:}

- Convenient online submission

- Rigorous peer review

- Immediate publication on acceptance

- Open access: articles freely available online

- High visibility within the field

- Retaining the copyright to your article

Submit your next manuscript at $>$ springeropen.com 